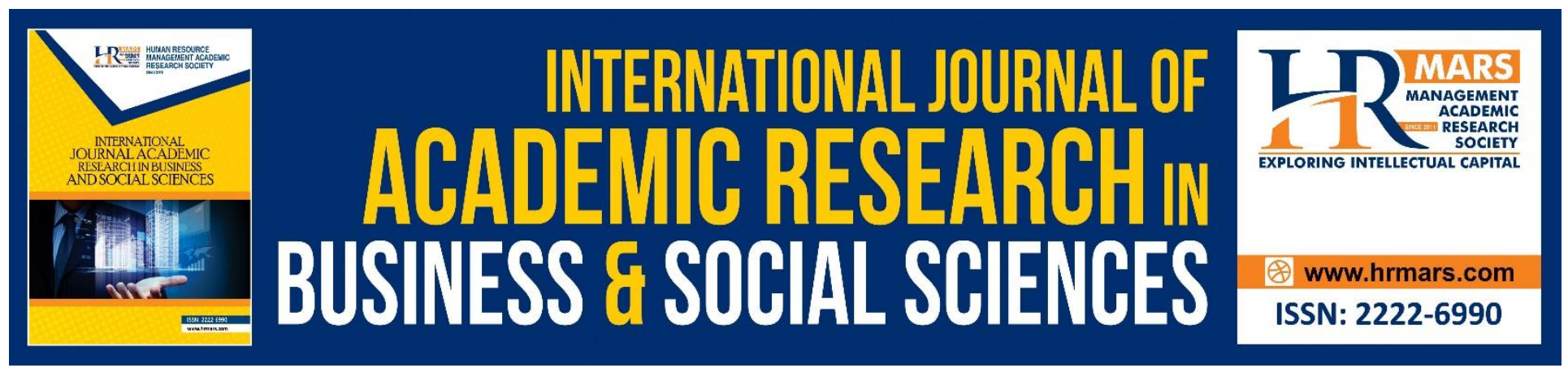

\title{
The Importance of Considering the Desire (Hajat) and Emergency (Darurat) in Fatwa Related to Basic Needs of Muslim Minority
}

Basri Ibrahim, Mohd Ali Mohd Yusuf, Firdaus Khairi

To Link this Article: http://dx.doi.org/10.6007/IJARBSS/v8-i10/4744

DOI: $10.6007 /$ IJARBSS/v8-i10/4744

Received: 04 Sept 2018, Revised: 17 Oct 2018, Accepted: 16 Oct 2018

Published Online: 31 October 2018

In-Text Citation: (Ibrahim, Yusuf, \& Khairi, 2018)

To Cite this Article: Ibrahim, B., Yusuf, M. A. M., \& Khairi, F. (2018). The Importance of Considering the Desire (Hajat) and Emergency (Darurat) in Fatwa Related to Basic Needs of Muslim Minority. International Journal of Academic Research in Business and Social Sciences, 8(10), 401-413.

Copyright: (C) 2018 The Author(s)

Published by Human Resource Management Academic Research Society (www.hrmars.com)

This article is published under the Creative Commons Attribution (CC BY 4.0) license. Anyone may reproduce, distribute, translate and create derivative works of this article (for both commercial and non-commercial purposes), subject to full attribution to the original publication and authors. The full terms of this license may be seen

at: http://creativecommons.org/licences/by/4.0/legalcode

Vol. 8, No. 10, 2018, Pg. 401 - 413

Full Terms \& Conditions of access and use can be found at http://hrmars.com/index.php/pages/detail/publication-ethics 


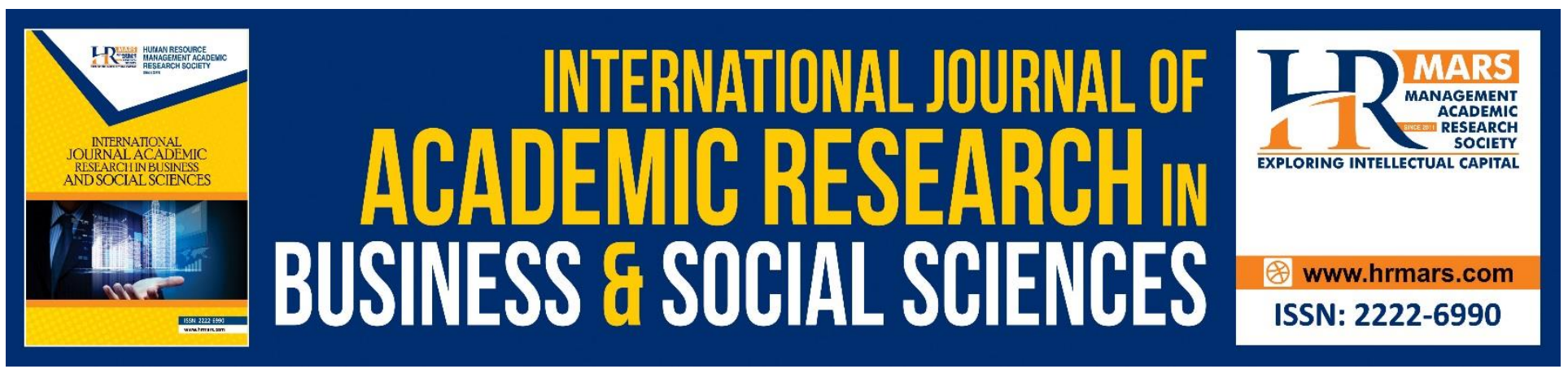

\title{
The Importance of Considering the Desire (Hajat) and Emergency (Darurat) in Fatwa Related to Basic Needs of Muslim Minority
}

\author{
${ }^{1}$ Basri Ibrahim, ${ }^{2}$ Mohd Ali Mohd Yusuf, ${ }^{3}$ Firdaus Khairi \\ ${ }^{1}$ Global Wisdom Academy, Universiti Islam Malaysia, Cyberjaya, Malaysia. \\ ${ }^{2}$ Faculty of Islamic Contemporary Studies, Universiti Sultan Zainal Abidin, Terengganu, Malaysia. \\ ${ }^{3}$ Center For Fundamental And Liberal Education, Universiti Malaysia Terengganu, Malaysia. \\ Corresponding Author: drbasr67@gmail.com
}

\begin{abstract}
Fatwa is something important in the life of Muslims, as it answers many arising questions among Muslim community regarding aqidah (faith), ibadah (worship) and akhlak (morals). The provided answer will ensure the life of Muslims to conform to the demand of holy Islamic teachings. Usually, fatwa will be produced by authorised personnel in Muslim countries and Muslim minority countries such as countries of Europe and others. Muslims do not just occupy Muslim countries, but also nonMuslim countries. To sustain the life, they require basic needs as they are included into the element of desire (hajat) and emergency (darurat) which is inevitable by them. But to obtaining of the basic needs does not always conform to the sharia laws. The main objective of this article is to explain the importance of considering the situation of desire and emergency in producing fatwa regarding the basic needs for Muslim minority. This article is based on qualitative study. Data were collected from classical books of Islamic jurisprudence, books of contemporary Islamic jurisprudence, websites and others, and then analysed to attain the outlined objective. This study found that the consideration of desire and emergency situation in producing fatwa of issues involving the life needs by authorised party, for Muslim minority group is an essential need to prevent difficulties faced in the life of Muslims but it must fulfill the condition determined by the scholars. If the situation of desire and emergency are not considered, the life of people in countries of Muslim minority will always be difficult, while avoiding difficulties from the Muslims is a demand in Islam itself.
\end{abstract}

Keywords: Fatwa, Hajat (Desire), Darurat (Emergency), Minority, Difficulty

\section{Introduction}

The field of fatwa takes an important position in the life of Muslim community, and it is not weird that the responsible person for the fatwa matters is appointed by the Muslim government 
throughout the world. The clash happening in Egypt and Palestine nowadays pictures the importance of fatwa in determining the future of those countries and affecting the value of the sacrificed life especially among civilians. When scholars produce a fatwa that obliges the killing of a group, the authority will put their best to enforce the fatwa and when scholars produce a fatwa saying that it is obligatory to support and supply help to the Muslims in Palestine, Muslims from all walks of life race to provide donation for the Muslims facing their Zionist enemy in the land.

In producing fatwa, it does not only involve references to proofs from al-Quran and al-Sunah, ijmak ulama (agreement of scholars) and qiyas (analogy), but also considers the culture and community custom and the extent of the desire and emergency situation faced by them. By taking into account of all these aspects, the fatwa produced will solve the problem of the community and be fair to the Muslim community either in the Muslim countries or non-Muslim countries.

Today, Muslim community does not just occupy Muslim countries, but also non-Muslim countries in which they become the minority citizens there. To survive the life, they need basic needs as the native people in the country. But, the obtaining of the basic needs is not compatible with Islamic teachings. In fact, most of them contradict with Islamic teachings which are relevant with the country's status of non-Muslim. Among the basic needs which becomes the issue among the Muslim community is the housing loan based on riba (interest) and others. If the Muslim community do not make the interest-based loan, it is difficult for them to get a house, while their need of living place is a part of desire and emergency, in which Islamic laws permit to do prohibited action and leaving a certain obligatory action. Therefore, a clear fatwa considering the situation of desire and emergency regarding the issue should be done to abolish the difficulties faced by the Muslims staying in the countries of Muslim minority.

The purpose of this article is to explain the need of celebrating the situation of desire and emergency in fatwa production performed by the authority in countries of Muslim minority. With that, it will prevent harms and difficulties to them in getting basic needs in the involved countries. Moreover, nowadays, non-Muslim countries such European countries and others have been occupied by a large population of Muslims and even some are born there and become the countries' citizens.

Writings on fatwa have been produced a lot by the scholars from the past until now. That also goes to the topic of desire and emergency in the discipline of Usul al-Fiqh (principles of Islamic jurisprudence). Among them are Dawabit al-Hajah Allati Tunazzilu Manzilah al-Darurat Wa Tatbiqatuha 'Ala al-ljtihadat al-Mu'asirah (al-Zair, 2010), al-Farq Bayna al-Darurat Wa al-Hajat Ma'a Ba'di Tatbiqat Mu'asirah (Ibn Bayyah, 1421H), al-Futya Wa Manahij al-Ifta' (Asyqar, 1396), al-Hajat al-Syar'iyyah Hududuha wa Qawa'iduha (Kafi, 2004) al-Ifta' 'Inda al-Shaykh al-Qaradawi: al-Manhaj Wa al-Tatbiq (Sabri, 2007), Dawabit al-ljtihad Wa al-Fatwa (Rayyan, 1994), al-Fatwa Fi al-Islam (alQasimi, 1332H), Fatwa-Fatwa Berkaitan Fiqh Semasa Di Malaysia (Ibrahim B, 2015), Metod Fatwa Al-Qardawi Dalam Menangani Isu-Isu Semasa (Basri, 2011) and others. However, a specific discussion on the desire and emergency need in fatwa production for Muslim minority group staying in non- 
INTERNATIONAL JOURNAL OF ACADEMIC RESEARCH IN BUSINESS AND SOCIAL SCIENCES Vol. 8, No. 10, Oct. 2018, E-ISSN: 2222-6990 ㄷ 2018 HRMARS

Muslim countries is rarely found. Therefore, this study is brought upon to explain the need of celebrating the desire and emergency in fatwa production for the group more specifically.

\section{Research Methodology}

The writing of this book was based on the documentation study in which the data collection was focused on classical books of Islamic jurisprudence, books of contemporary Islamic jurisprudence, websites and others. It did not involve field study, suitable with its title which focused more to the call of understanding and learning the current jurisprudence among Muslim community of this postmodernism era. It was not more than a spark of thought to create awareness to the Muslim community of the importance of understanding, learning and mastering the temporary Islamic jurisprudence and for the coming years, so that Muslim community will not be left behind compared to other non-Muslim community in mastering the current knowledge which is related to daily life.

\section{Findings}

Fatwa is an answer given by a scholar of mufti to the issues posed to them, involving various disciplines and fields of life. The answer given is to ensure that the life of Muslim community goes in alignment with the sacred teachings of Islam and does not go fall into the valley of Satan's fraud which ignores the law of permission (halal) and prohibition (haram).

Fatwa institution is one of important government agencies in the administration of religious affairs and mufti is one of the religious officials that had the same level as the preachers, the reciters, Imam and administrator of hajj affairs in the time of Rasulullah p.b.u.h.

Fatwa is very important in embarking the life and the existence of fatwa enables the sharia laws to be enforced according to sharia methods. Fatwa plays an important role in the progress of Islamic laws and sharia laws. With the position, fatwa institution is given the main attention by world of Islam.

The importance of fatwa becomes more obvious in the universal human life as the main mechanism of explaining the sharia laws and the propagation of the teaching includes the aspect of faith and worship in the human life. Looking at the importance of fatwa institution and the role of mufti in Islam, it shows that mufti is the most important figure in the community and Islamic government.

Fatwa has important role in the Islamic judiciary, as it functions to explain the laws which do not have clear references to the community. During the ruling of four caliphates, the power of fatwa did not only fall under the caliphate's authority, but also under the scholars among the companions. This was because:

a. The public could not understand the references unless there was somebody explaining to them. 
b. References from al-Qur'an and al-Sunnah did not spread widely among the Muslim community, as al-Qur'an itself in the early stage, was only memorised and the scriptures were kept in the house of Rasulullah p.b.u.h. and several companions, while sunnah was not compiled as nowadays.

c. References of al-Qur'an and al-Sunnah explained the laws regarding the past events and not of assumptions (Yaacob, 2007).

d. Mufti served as an the announcer of anything that comes from Allah, not different from the prophet. Mufti also delivered his commandment to the community (Rayyan, 2004).

\section{Definition of Fatwa}

Fatwa literally means to answer or explain a particular problem (Rayyan, 2004). From sharia aspect, it means to explain the sharia laws according to al-Kitab, al-Sunnah, ljmak and also qiyas (Rusyd, n.d.).

In al-Qamus al-Fiqhi, fatwa means to answer the problems of sharia or laws that create problem in the solution for somebody (Jayb, 2008). Meanwhile, in Mu'jam Lughah al-Fuqaha', fatwa means the sharia laws explained by a knowledgeable in the figh knowledge, as an answer to the asker of the matter (Rawwas \& Qasibiy, 1985).

The person who is responsible of producing fatwa is called as mufti. His task is to produce fatwa and this is called as ifta'. The answer posed by a mufti is called as fatwa. The party asking the mufti on a certain problem is called a mustafti (Zaydan, 1987).

Shortly, what is called a fatwa is the production of law performed by a knowledgeable or wellversed person of a certain issue happening in the community which does not have any clear reference in al-Kitab, al-Sunnah, ijmak or qiyas, by using the four agreed sources.

Definition of Desire (Hajat) and Emergency (Darurat)

Desire (hajat) literally means a need of something (al-Zabidi, 1994). Technically, the term means something needed to get a comfort and avoiding difficulty which normally causes hardship in life. If it is not fulfilled, it will lead to a difficulty and hardship in life, but it might not lead to destruction (alSyatibi, t.th). Meanwhile, emergency literally means something inevitable (Ibrahim, et.al, 2004).

Technically, it means a need which can reach the destructing or almost destructing level, if it is not fulfilled. It also permits the prohibited action (al-Suyuti,t.th).

Difference between Desire (hajat) And Emergency (Darurat)

Differences between Desire and Emergency are: 
a. Desire involves a lower level of difficulty compared to emergency which involves larger and higher level of harm. Every difficulty causing destruction or loss of any of the five objectives of sharia which are religion, life, mind, properties or dignity, is considered as emergency. Every difficulty which does not intrude into any of the five objectives of sharia is considered as a desire.

b. Desire involves prohibition onto a reason which causes an allowed action to be prohibited, while emergency is based on prohibition of the body of forbidden matter itself. The prohibition to the reason causing an allowed matter to be prohibited is such as wearing a confiscated cloth from somebody through illegal way to perform prayer. Performing prayer using a cloth obtained from the way is prohibited although the prayer itself is demanded to be performed. The prohibition onto the body of prohibited matter itself refers to the prohibition of the matter from the beginning such as the prohibition of eating pork, drinking liquor, stealing and others as they lead to harms (Kafi, 2004).

c. Desire initiates motivation of striving for comfort and easiness to get something, while emergency initiates a desperation and need to do something prohibited. For example, the desire allows woman to wear silk and gold. It is allowed to reach for perfection in taking benefits from the things stated above. On the other hand, in the case of emergency, failure of doing the prohibited action will lead to a death, illness or weakness in performing various sharia obligations such as eating carcass and others.

d. Desire involves permanent law, while emergency involves temporary law. Even though both involves difficulty and the permission of doing prohibited action. Desire encompasses obligatory law such as the guarantee done by the government to the businessmen to avoid difficulty and prohibited matter among public such as the prohibition of Muslim teenagers to marry the people of the book in avoiding the Muslim women from not being married by Muslim men. Emergency involves obligatory laws such as the obligation of eating pork to avoid self-destruction, prohibition such as killing people to avoid being killed and neutral law such as uttering words of apostasy while being forced to do that (Kafi,2004.

\section{Conditions of Considering the Desire}

Not all situations of desire permit somebody to do prohibited action or leaving obligatory action, indeed he must fulfil several conditions which are:

a. The desire must have a strong basis from the law and walks aligned with the principles and objectives of sharia (al-Syatibi, t.th). Such as human cloning is not allowed to be done, even in the purpose of getting progeny as it will lead to a chaos in the descendants, as guarding the descendants is one of the sharia objectives (al-Syuwairikh, 2007).

b. The desire must involve the peak of the difficulty or hardship or extraordinary hardship which could not be endured by the human ('Izuddin, 1991). Ordinary difficulty or the one which can 
be withstood by human does not affect anything to the taking of prohibited action or the leaving of obligatory action.

c. The desire must be a possible matter or involve a strong assumption. This is because the law to desire is the law of exception bound to get exemption. Strong assumption substitutes the confidence. For example, a patient that assumes strongly that he cannot go into fasting is allowed to break the fast to celebrate the desire (Nujaim, 1997).

d. It is convinced that the desire cannot be overcome by doing the commanded way of Allah s.w.t, indeed he must do an opposite action to the commandment or doing prohibited action (Al-Zair, 2010).

\section{Conditions of Considering the Emergency}

Not all situations regarded as emergency, are admitted as a real emergency such as the situations of desire discussed above, instead it needs to fulfil several conditions to qualify it to be in the emergency status allowing the performing of prohibited action or leaving obligatory action. The conditions are:

a. The emergency really occurs and not something that will happen. In other words, in reality, the worries of destruction to the self and properties have already happened. This is determined by the experience gone through or harms to one of the five sharia objectives which are the importance of guarding the religion, life, dignity, mind and properties (alZuhaili, 1985).

b. Emergency needs the people facing it to contradict with the commandments and prohibitions of sharia. In other words, there is no other permitted way that can be exploited to overcome the emergency situation.

c. The emergency really insisting which is raising worries that it will lead destruction of life and properties if it is not done. For example, a person is forced to eat carcass in which if he does not eat it, his life or part of his body is in danger.

d. Emergency does not contradict with the basic principles of sharia such as the obligation of guarding other people's right, upholding justice, avoiding harm, obligation of guarding the principles of religion and bases of Islamic faith such as not permitting adultery, murder and apostasy in any situation at all.

e. Emergency involves the taking of prohibited action in the needed rate only and not more than that to avoid harm, as permission of prohibited action is a form of emergency, while the emergency itself must be determined according to what is needed only.

f. The emergency if it involves treatment, must take into account the suggestion by just and trusted medical experts from religion and knowledge aspect. At the same time, it should be 
INTERNATIONAL JOURNAL OF ACADEMIC RESEARCH IN BUSINESS AND SOCIAL SCIENCES

Vol. 8, No. 10, Oct. 2018, E-ISSN: 2222-6990 @ 2018 HRMARS

ensured that there is no other alternate method which can be applied except the treatment which involves the prohibited action.

g. The emergency if it involves public, the authority must ensure the existence of tyranny, vivid harm, horrible difficulty to the country if the prohibited action is not taken such as the permission of paying an amount of money to the country of enemy to avoid terrifying attack from the enemy's country or to maintain the stability and prosperity of the country (al-Zuhaili, 1985).

The Importance of Celebrating Desire and Emergency in Producing Fatwa for the Muslim Minority Group

There are Muslim community who become minority group in several countries in the world such as European countries, United States of America, Canada, Latin America, Russia, several African countries, Singapore, Thailand, Philippines, Australia, New Zealand, China, Korea, Japan and others. They are facing interaction with the community in the countries they inhabit to get basic life needs and daily needs. Getting legal daily needs and not contradicting with sharia does not raise any big problem for them, instead the one raising big problem is the obtaining of basic life needs in the countries such as the need of getting a house as living place, substituting rented house and others.

Realising the fact, European Islamic Council has decided that the Muslims in Europe are allowed to borrow money from bank of interest to purchase house for themselves and their family, in condition of not owning any house at all, the house purchased is the basic need and not having any other financial resources adequate of buying the house with cash (Bayyah,1421H).

This fatwa is based on:

a. Celebrating the principle of jurisprudence "emergency permits prohibited action" which is agreed among scholars. This is taken from al-Quran reference such as Allah s.w.t's words:

Means: ... indeed Allah has explained one by one to you about what He has prohibited to you, except what you are desperate to eat? And truly most of the human want to deviate you by their lust without basing on knowledge. Truly your God, He is more knowledgeable than the people who transgress.

(al-An'am 6:119)

b. Celebrating the principle of jurisprudence "desire takes the place of emergency", in which scholars have decided that desire takes the position of emergency in the general or specific form". Desire as explained in the previous discussion, will put a Muslim to be in difficulty if the desired action is not performed even though he can still be alive. In fact, Allah s.w.t abolishes difficulty from Muslim people. It is taken from the reference of Allah s.w.t.'s words: 
INTERNATIONAL JOURNAL OF ACADEMIC RESEARCH IN BUSINESS AND SOCIAL SCIENCES Vol. 8, No. 10, Oct. 2018, E-ISSN: 2222-6990 @ 2018 HRMARS

Means:... Allah does not want you to bear the difficulty (hardship), but He wants to cleanse (purify) you and perfect His bounties unto you, so that you will be grateful.

(al-Ma'idah 5:6)

Living place that can avoid difficulty from Muslims is a house which is suitable in the aspect of location, width and the basic facilities provided. Living place or living house is a need to Muslims and Muslim families. Allah s.w.t said clearly on this in His words:

Means: And Allah created for you houses (which you built) a living place; and He makes them for you from the skin of the livestock: tents (place of shelter), which you find it light in weight (mobile) as you travel and you stop; and (He also makes for you) from various wools of the livestock, many house appliances and ornaments, (for you to use) until a certain time.

(al-Nahl 16:80)

Prophet p.b.u.h. made a wide house as one of the four elements that prosper human. On the other hand, rented house cannot fulfil the need of living house for Muslims in the real meaning and does not provide them peace. Besides that, it also forces Muslims to pay a large amount of money to non-Muslims and the payment does not grant permanent ownership. Instead, they are exposed to leaving the rented house as the family members increase, age increases, income declines or a total loss of income forcing them to be homeless.

Therefore, the ownership of living house is considered as adequate to support their basic need. By owning the house, Muslims are given space to choose a house close to the mosque, Islamic centre, and Islamic school, until it provides space for Muslims to form a small but strong Muslim community in the big community of non-Muslims. Their children can know each other. The relationship between each other can be strengthen and they can live in the radius of Islamic teaching and its high values. Besides that, it provides opportunity for the Muslim minority to repair and improve their life standard as a qualification for them to be the best people produced for the human. They will appear as a good role model of Muslim community life in front of non-Muslims. It also eases them to liberate from economic pressure and to do preaching activity among non-Muslim community (Bayyah,1421H).

c. According to view of imam Abu Hanifah and his senior colleague Imam Muhammad Hasan al-Syaibani, Sufyan al-Thawri, Ibrahim al-Nakha'i, a narration narrated from imam Ahmad bin Hanbal and the view chosen by syeikhul Islam Ibn Taymiyyah, which permit the interestbased business interaction between Muslims and non-Muslims in non-Muslim country. This is because, according to this group, Muslims are not burdened to uphold sharia laws in the form of civil, economics, politics and others related to general laws in a country in which its people do not believe in Islamic teaching, as it is out of their authority, as Allah s.w.t does not teach Muslims to do something not in their ability. The prohibition of interest relates to desire of community, country's philosophy, social course and economic course. 
Minority Muslims are demanded to uphold individual sharia laws such as laws regarding worship, meal, beverage, and clothing. They also include marriage, divorce, reunion (rujuk), period of grief (idah), inheritance and others which are included into family laws. If the Muslims are not allowed to uphold the laws, they are asked to migrate to other countries to widen the space for them to practise the laws.

Besides that, if the Muslims are not involved in the interaction and business which are based on interest in the non-Muslim countries, it will make the perseverance of Muslims to practise Islamic teachings a cause of their weakness economically and loss financially. Despite, Islam should strengthen Muslim people and not weaken them, improve their achievement and not decrease it and benefit them and not harm them. Some of the scholars of old school thought permit Muslims to inherit properties from non-Muslims by the proof of "Islam improves their life standard and does not decrease their rights" and "Islam is high and there is no other which is higher than Islam" (Bayyah,1421H).

Regarding the assumption of certain people saying that scholars of Hanafi sect only allow interaction of interest (riba), it is only allowed in the taking and not in giving, as there is no benefit of Muslims giving interest. Therefore,, they should not interact in the interest-based interaction except by two conditions which are inviting forgiveness to the Muslims and not causing fraud and treachery to the Muslims.

To answer the point above, it is gladly informed that it cannot be accepted, as proven itself by the view posed by Muhammad bin Hasan al-Syaibani in al-Sayr al-Kabir. This is because the giver of interest also enjoys the benefit of the interest as they are finally able to own a house. Based on the confession made by Muslim minority living in European countries, they prove that instalment done to purchase the house is as much as the rent paid to the landlord, and sometimes is less than the rent. This means that if the Muslims there are prohibited from borrowing money from bank of interest, we have prohibited them from getting their own house for them and for their families. In fact, the need of living house is included into the basic needs needed by the Muslims. Most probably, Muslims spend their time paying rent for 20 to 30 years or more than that and at the same time they do not own any living house. Despite, they should have succeeded in owning a living house (Bayyah,1421H).

If the business interaction is not permitted in Hanafi sect, it should still be permitted by scholars as the Muslim people in the involved country are facing the case of desire taking place of emergency. It should be more if the Muslims there are making payment involving interest and not taking the interest itself. The prohibition in the beginning focuses on consuming interest as explained by verses of al-Quran. Meanwhile, the prohibition of taking interest in the form of riba is for the sake of closing the door of harms towards Muslims. It is included into the prohibition of mean or method and not of the objectives. The famous principle of jurisprudence explaining that "something prohibited due to the body is not permitted except in the case of emergency, and something prohibited due to the prevention of harm is permitted in the desire" (Bayyah,1421H). 
Although this is the fatwa produced by European Islamic Council, however, in the early part of the fatwa text, it is stated that Muslim community agree on the prohibition of riba in the normal situation and it is included into seven major sins which is announced war by Allah and His messenger to the people who consume it. Interests given by conventional bank are prohibited riba by sharia.

Fatwa council also urges Muslims who is staying in Europe of not forgetting to the complementary method to the two methods discussed above which are "something permitted due to emergency, is determined according to rate of need". Due to that, they should not permit at all the loan made to purchase home for the sake of business as it violates the above methods and exceeds the need of desire and emergency (Bayyah,1421H).

Muslims are also urged to find other alternatives that conform to the sharia, which contain no doubt (syubhah) as they can do. For example, attempt to form companies which are Islamoriented that can build homes for Muslims by posing easy terms and conditions which can be fulfilled by Muslim majority.

Council also urges the Islamic association in Europe to form conference with the bank party in their countries to form a housing loan which is sharia-compatible such as forming Bai'i Bi al-Taqsit (instalment of sale) involving increase of payment due to increase of payment duration. By forming that, they will get a large number of customers among Muslims. Moreover, recently, some of European banks open their branches in several Islamic countries by introducing sharia-compatible products to attract customers among Muslims (Bayyah,1421H).

\section{Conclusion}

Based on above discussions, it is a need for the mean time for the authority to produce fatwa in the countries of Muslim minority especially in European countries to celebrate the desire and emergency faced by them to ease them in getting basic needs such as living house and others based on conditions such as not owning any house, the bought house is the basic need and not of business interest and not having money to purchase the house with cash. This is applicable in the situation of no other sharia-compatible alternatives which could not be obtained or performed. If the situation of desire and emergency like this is not being considered, Muslims there would face difficulty in owning living house, as the need of living house is a basic need and also an element which prospers their life. Moreover that Islam does not weaken its people. Instead, it always strives to strengthen its people wherever they are.

To ask Muslim people in the minority countries to migrate to other countries or to Islamic countries itself, is not the best solution, as most of them have already occupied the country for years and were born there. In fact, some of them assume the country as their own blood land. Except that their religion differs with the religion of other communities in the countries. Moreover that they are not oppressed unjustly like the one happening in Mecca a long time ago forcing them to be 
INTERNATIONAL JOURNAL OF ACADEMIC RESEARCH IN BUSINESS AND SOCIAL SCIENCES

Vol. 8, No. 10, Oct. 2018, E-ISSN: 2222-6990 ㄷ 2018 HRMARS

commanded to migrate to Medina. Recently, when the crisis happened in Syria and Iraq, hundreds of thousand Muslim people migrated to European countries to start a new life.

\section{Corresponding Author}

Basri Ibrahim, Jamalullail Professorial Chair, Global Wisdom Academy, Universiti Islam Malaysia, Cyberjaya, Malaysia.

Email: drbasr67@gmail.com.

\section{Acknowledgement}

Special thanks to the GWA, Universiti Islam Malaysia, Cyberjaya for funding the research.

\section{References}

Al-Asqar, S. (1396H), al-Futya Wa Manahij al-Ifta', Kuwait: Maktabah al-Manar al-Islamiyah. Bayyah, A.S.M.I. (1421H). al-Farq Bayna al-Darurat Wa al-Hajat Ma'a Ba'di Tatbiqat Mu'asirah. Majalah Dirasat lqtisadiyat Islamiyyat. vol. 8. no. 1.

Ibrahim, A, Muntasir, A. H, al-Sawalihi, A, and Ahmad, M.K. (2004). Al-Mu'jam al-Wasit. Egypt: Maktabah al-Syuruq al-Dawliyyah.

Ibrahim, B., Ali, E., Tajuddin, E. M., \& Mohd, Z. (2015). Fatwa-Fatwa Berkaitan Fiqh Semasa Di Malaysia. Selangor: al-Hidayah House Of Publisher Sdn Bhd.

Ibrahim, B. (2011). Metod Fatwa Al-Qardawi Dalam Menangani Isu-Isu Semasa. Selangor: al-Hidayah House Of Publisher Sdn Bhd.

'Izuddin, A.S. (1991). Qawa'id al-Ahkam Fi Masalih al-Anam. Muhaqiq: Taha 'Abd Rauf Sa'ad. Cairo: Maktabah Kulliyat al-Azhariyyah.

Jayb, S.A.(1988). al-Qamus al-Fiqhi Lughatan Wa Istilahan, Damsyiq: Dar al-Fikr.

Kafi, A.(2004). al-Hajat al-Syar'iyyah Hududuha wa Qawa'iduha. Beirut; Dar al-Kutub al-'Ilmiyyah.

Nujaim, Z. A.(1997) al-Bahr al-Ra'iq Syarah Kanz al-Daqa'iq. Beirut: Dar al-Kutub al-'Ilmiyyah.

al-Qasimi, M. J.D.( 1332H). al-Fatwa Fi al-Islam, Beirut: Dar al-Kutub al-'Ilmiyyah.

Rayyan, A.A.T. (1994). Dawabit al-ljtihad Wa al-Fatwa. Cairo: Jabhah Ulama al-Azhar.

Rawwas, M \& Qasibi, H.S.(1985). Mu'jam Lughah al-Fuqaha', Jordan: Dar al-Nafa'is.

Rusyd, M.Q I. (n.d), Fatawa Ibn Rusyd, vol. 3, Beirut: Dar al-Gharbi al-Islami.

Sabri, M.( 2007 ). al-Ifta' Inda al-Shaykh al-Qaradawi: al-Manhaj Wa al-Tatbiq. Multaqa al-Imam alQardawi. Doha: Hotel Ridezt Calton. 14-16 Julai.

Al-Suyuti, A.R. (T.th.) al-Asybah wa al-Naza'ir. Egypt: Maktabah Mustafa al-Babi al-Halabi.

Al-Syatibi, A.I. (n.d). al-Muwafaqat Fi Usul al-Syari'ah. Beirut: Dar al-Ma'rifah.

Al-Syatibi, A.I. (n.d). al-I'tisam. Muhaqqiq: Masyhur bin Salman Ali Salman. Maktabah al-Tawhid.

Al-Syuwairikh, S. (2007). Ahkam Handasah Wirathiyah. Maktabah Kunuz Isybilia.

Yaacob, A. M. (2007). Perkembangan Institusi Mufti Di Malaysia, Kertas Kerja Seminar Serantau, Mufti dan Fatwa, Kuala Lumpur: Institut Kefahaman Islam Malaysia ( IKIM ) 23 \& 24 September.

Al-Zabidi, S.M.Murtada.H.(1994). Taj al-Arus. Kuwait: Wazarah al-Irsyad wa al-Anba'.

Zaydan, A.(2002). al-Wajiz Fi Usul al-Fiqh, Beirut: Mu'assasah al-Risalah Li al-Tiba'ah Wa al-Nasyri Wa al-Tawzi'. 
INTERNATIONAL JOURNAL OF ACADEMIC RESEARCH IN BUSINESS AND SOCIAL SCIENCES

Vol. 8, No. 10, Oct. 2018, E-ISSN: 2222-6990 ㄷ 2018 HRMARS

Al-Zair, W.S.D. (2010). Dawabit al-Hajah Allati Tunazzilu Manzilah al-Darurat Wa Tatbiqatuha 'Ala alIjtihadat al-Mu'asirah. Majalah Jami'ah al-Dimasyq Li al-'Ulum al-Iqtisadiyyah Wa alQanuniyyah, vol. 26. no. 1.

Al-Zuhaili, W.(1985). Nazariyah al-Darurah al-Syar'iyyah Muqaranah Ma'a al-Qanun al-Wad'i. Beirut: Mu'sassah al-Risalah. 